\title{
COMPUTER ASSISTED INTERPRETER TRAINING FOR STUDENTS WHO ARE NOT FOREIGN LANGUAGE MAJORS
}

\author{
Sheng-jie CHEN, PhD. \\ Department of Applied Foreign Languages \\ National Taiwan University of Science and Technology \\ 43, Keelung Road, Section 4, Taipei City, Taiwan \\ shengjie@mail.ntust.edu.tw or ntustjason@yahoo.com
}

\begin{abstract}
The aim of the existing case study was to investigate the implications of applying computers to teaching interpreting to students who were not foreign language majors. Some researchers argued that interpreting courses are very difficult, so they should be offered to qualified post-graduate students instead of undergraduate students. However, most undergraduate programs in Taiwan offer interpretation courses. In addition, in China two-semester interpreter training courses have even been offered to most undergraduate students who were not foreign language majors. Furthermore, computers have been widely used in interpreter training, but no research has been available that investigated how to apply computer assisted interpreter training (CAIT) to teaching interpreting to students who are not foreign language majors. Qualitative research methods have been used to collect and analyze the data to complete the report in this study. Participants consisted of the author and the 18 students, who were not foreign language majors, taking a computer assisted interpreter training course that the author offered in a university in Taipei, Taiwan, in 2009. The results of the study indicated that CAIT may be developed into IM (the interpretation method) of foreign language teaching to teach students who are not foreign language majors.
\end{abstract}

\section{非外文系電腦輔助口譯教學}

\section{摘要}

本個案研究旨在探討如何運用電腦輔助口暲教學於教授外系(非外文系)的學生。有些專家主 張口譯課很困難所以只能在研究所開設給有資格的學生學習，而不應該開給大學部的學生 。但是在台灣大部份的大學部都有開口譯課。在中國甚至大部份的外系(非外文系)都在開為 期兩個學期的口譯課。奄腦廣泛的運用於口譯教學，但是卻很少研究探討如何運用電腦於 外系的口譯教學。本研究採用質的方式收集與分析資料完成本論文，寅驗參與者包括筆者 與選修筆者2009年在台北一所大學開設的電腦輔助口譯課的18位外系的學生。本研究結果 顆示電腦輔助口譯教學可以發展成為獨樹一格的教學法，以透過教授口譯訓練技巧的方式 教外系學生外文。

\section{Special terms}




\section{Comparative Legilinguistics 4/2010}

- Interpreting: Orally translating a spoken message from a source language into a target language.

- Interpreting Method (IM): Using interpreter training tasks, such as reading aloud, shadowing, summarizing, consecutive interpreting, and simultaneous interpreting with the assistance of computers to enhance students' foreign language listening comprehension, speaking, reading, and interpretation skills.

- Shadowing: Listening to a spoken message and repeating after it word by word at the same time.

- Consecutive interpretation (CI): While the speaker is speaking, the interpreter listens and takes notes. When the speaker pauses after speaking for a certain period of time (as short as a sentence and as long as half an hour or even longer), the interpreter refers to the notes and interprets into the target language.

- Short consecutive interpretation (short CI): The speaker speaks and pauses after every one or two sentences. During the pauses, the interpreter interprets into the target language.

- Simultaneous interpretation(SI): When the speaker starts speaking, the interpreter starts interpreting at the same time; when the speaker finishes speaking, the interpreter finishes interpreting at the same time although there is a short lag between the speaker's speech and the interpreter's rendition.

\section{Introduction}

The Interpretation Method (IM) of language teaching, advocated by Dr. ShengJie Chen of the National Taiwan University of Science and Technology in Taiwan, is an innovative foreign language teaching method developed from CAIT (computer assisted interpreter training) (Chen, 2010a), which based itself on the experiments of using interpreter training tasks and multimedia computers to teach interpreting in a graduate institute of translation and interpretation and other post-graduate interpreter training courses in Taiwan for five years. The existing study was an attempt to investigate the implications of using IM in teaching interpreting, listening comprehension, speaking, and reading, through performing interpreter training tasks, to students who were not foreign language majors and to establish an alternative foreign language teaching method. Hardly any research has been available that investigated the use of IM in teaching students who were not foreign language majors. This study attempted to bridge the gap. I decided to offer the interpretation course in IM to non-foreign language majors for the following reasons: First, in mainland China, interpreting is currently taught in most BA programs as a one-year course in the senior year (Dawrant and Hong, 2001). Second, in Taiwan, many individuals who became interpreters had diverse backgrounds including both those who majored in foreign languages and those who didn't; most interpreters were specialized in at least two fields; many outstanding interpreters were not English or foreign language majors (Guo Li Tai Wan Shi Fan Da Xue Fan Yi Yan Jiu Suo and Tai Wan Jing Ji Yan Jiu Yuan, 2004). Third, it is hoped that IM may enhance the competitiveness of the non-foreign-language majors in the university involved and to offer them an opportunity to learn a second skill-interpreting. Fourth, 
several professors in Taiwan, who were not foreign language majors, have told me that over twenty years ago when they had just returned to Taiwan after advanced studies in the United States, they were asked to interpret at conferences without receiving any previous training. Similar things are still happening in Taiwan. Finally, IM may be offered as an alternative foreign language teaching approach in the foreign language classroom.

\section{Literature review}

The following review was excerpted form Chen (2010a).

According to Sandrelli and Hawkins (2006), CAIT is using multimedia computers to facilitate interpreter training, an interpreter training idea derived from Computer Assisted Language Learning (CALL) (Sandrelli 2003).

\section{Existing types of CAIT}

Chen (2010a) indicated that CAIT may be divided mainly into the following categories: (1) Websites that offered audio, video, and text learning materials for interpreter training (Yang, 2002, Yang, 2003a, \& Yang, 2003b); (2) Moodle online learning community (Chang, 2006); (3) computer software packages, including the Liaison Interpreter Training CD ROM (Sandrelli, 2001), Interpreter Training CD ROMs, Black Box 4.0 (Sandrelli and Hawkins, 2006), and Interpretations (Sandrelli, 2003), that carried video or audio materials for students to interpret and compare their interpretations with the instructor's interpretation models or source language scripts (Sandrelli, 2001;Sandrelli, 2003); (4) fully fledged software that simulated interpretation booths (Sandrelli and Hawkins, 2006); (5) the most advanced Virtual Interpreting Environment (VIE) that offered software that facilitated interpreting booths for interpreter training (Sandrelli and Hawkins, 2006); (6) and virtual learning environment (VLE) that contained many learning tools (Sandrelli, A. \& Jerez, M, 2007). Chen (2010b) conducted a Black Board Learning System based interpreter training course in the graduate school of applied foreign languages at a university in Taiwan that involved the use of Eight working languages (Mandarin Chinese, English, Taiwanese, Cantonese, French, Russian, Buryat, and Spanish).CAIT was used throughout the course.

\section{Research design}

I used grounded theory (GT), a qualitative research method, to conduct the existing study. GT is a methodological qualitative research method used in such areas as social sciences and education emphasizing the generating of theory from data throughout the research process (Strauss \& Corbin, 1990). GT works differently from traditional research in that instead of starting by researching and developing a hypothesis, the first phase of research in GT is data collection by using various methods (Allan, 2003), such as field notes, audio or video recording, interview....etc. Multiple data collecting methods were used in the existing study, and the data consisted of the teacher/researcher's observation notes, head notes, and reflective notes, as well as the 


\section{Comparative Legilinguistics 4/2010}

students' oral and written output. Open coding, axial coding, and selective coding (Strauss \& Corbin, 1998) were used to analyze the data to complete the report.

\section{Participants}

The participants of the existing study consisted of the instructor and 18 students of a course titled "Basic Interpretation". The teacher has been teaching interpreting in college for more than 10 years and has been an active conference interpreter of English and Chinese for 12 years. He has also been conducting research in interpreter training, CAIT, and non-language specific interpreter training. The student participants consisted of 18 students, who were not foreign language majors. They came from different departments in a university of science and technology in northern Taiwan. Mandarin Chinese is their first language and English their second language. They have all studied English for approximately 8 years.

\section{Research Questions}

This study attempted to answer the following questions related to IM:

1. What is IM?

2. What are the theoretical backgrounds of IM ?

3. How to design a course in IM for teaching students who are not foreign language majors?

4. How to implement a course in IM?

5. What are the materials and equipments used?

6. How are the tests administered?

7. How did the students react?

\section{An interpretation course in IM for students who are not foreign language majors}

\section{IM}

In IM, interpreter training tasks, e.g. shadowing, sight translation, consecutive interpreting, summarizing, CI note taking, and simultaneous interpreting, are used to enhance students' English and interpretation skills. CD ROMs together with a textbook are used as teaching materials. The instructor plays the CD ROM on the computer and turns on the subtitles of both the source language and the target language, the video, and the audio. As the training proceeds, the students interpret by referring to the subtitles and watching the video. Both the training tasks and materials are recycled in each class session. As the training continues, the subtitles are turned off one by one until finally both English and Chinese subtitles are turned off and the students have to interpret by only watching the video and listening to the soundtracks.

Theoretical basis

IM is solidly based on learning theories involving social cognitive theory, modeling, explanation, scaffolding, zone of proximal development, and offering feedback. This section deals with the theoretical backgrounds on which IM is based. Relevant theories will be introduced followed by explanations on how they may be applied to IM, which in turn will be followed by examples.

Social cognitive theory: Social cognitive theory is derived from social learning theory proposed by Miller and Dollard (1941), who posited that people may be motivated 
to learn a particular behavior by observations. The observer may solidify that acquired behavior by mimicking the observed actions and would then be rewarded with positive reinforcement (Miller and Dollard, 1941). In IM, students are motivated to observe as the instructor plays the video in the CD ROM. They imitate the interpretation by watching the video and listening to the soundtracks of the source language (English), watching the video, and reading the subtitles while the instructor reinforces positively by approving the interpretation and asking the next student to interpret or to do another task.

Modeling: Modeling, the first phase in instructional scaffolding, is defined as "teaching behavior that shows how one should feel, think or act within a given situation." (Hogan and Pressley, 1997, 20). The three types of modeling are: think aloud modeling, talk-aloud modeling, and performance modeling. In IM, think aloud modeling is used to explain the strategies of performing a training task as demonstrated by the instructor. In IM, talk-aloud modeling is a showing of the completion of the interpreter training task accompanied by explaining the thought process or problem solving strategies that brought the instructor to his conclusion. Finally, performance modeling is simply the demonstration of the interpreter training task to be completed without giving further verbal explanations.

Explanation: It is essential for the instructor to explain in addition to modeling. Explanation should be “ explicit statements adjusted to fit the learners' emerging understandings about what is being learned (declarative or prepositional knowledge), why and when it is used (conditional or situational knowledge), and how it is used (procedural knowledge)" (Hogan and Pressley, 1997, 17). In IM, the instructor not only models, by demonstrating how to perform a certain task, but also delineates various training tasks and modes of interpreting and explains how to perform them in a way comprehensible to the students.

Scaffolding: Scaffolds are structures that are temporarily set up at the construction site to support workers when they are performing tasks that they cannot do without those supports (Herber and Herber, 1993, 138). According to Herber and Herber (1993), instructional scaffolding is a pedagogical strategy resembling construction scaffolds. To help learners understand new contents and processes at the preliminary phase, the instructor provides scaffolding. As soon as the students become familiar with the contents and processes, the instructor removes the scaffolding for the students to perform the task by themselves. In IM, the instructor offers scaffolding by explaining to the students how to perform the interpreter training tasks, e.g. consecutive interpreting, showing them how to do them, and requiring the students to perform them by the supports of the subtitles, audio, and video. As the training proceeds, the instructor removes the scaffolding by stopping giving instructions, and turning off the subtitles one by one until finally the students have to perform various training tasks and perform various modes of interpreting without any support of the subtitles.

Zone of proximal development ( $Z P D)$ : Vygotsky posited that a child imitates an adult's example and gradually develops the skills to perform tasks without assistance; in addition, according to Vygotsky, the zone of proximal development is defined as:

"The distance between the actual developmental level as determined by independent problem solving and the level of potential development as 


\section{Comparative Legilinguistics 4/2010}

determined through problem solving under adult guidance, or in collaboration with more capable peers." (Vygotsky, 1978, 86).

Although Vygotsky's ZPD were intended strictly for problem solving, Tharp and Gallimore (1988) indicated that ZPD may be expanded to investigate other kinds of skills, such as cultural zones, individual zones, and skill-oriented zones. In IM, the ZPD is skill-oriented, and it is the distance between the actual development level as determined by students' ability to interpret independently and the potential interpretation ability that students attain through imitating the interpretation by repeating after the speaker (e.g. when reading aloud) and reading the subtitles on the computer screen (e.g. while doing consecutive interpretation) under the instructor's guidance and by working with peers who are more competent.

Offering feedbacks: As the students learn the new materials, the instructor should constantly check their comprehension and give positive feedback or corrective feedback "verifying and clarifying student understanding "(Hogan and Pressley, 1997, 18-19). In IM, when the students make obvious mistakes in pronunciation or interpreting, the instructor offers corrective feedback. The instructor offers affirmative feedback to encourage students to develop interpretation flexibility when the interpretation is innovative. It is important to offer affirmative feedback when students interpret in different but acceptable ways because students need to develop flexibility and such interpretation strategies as paraphrasing, summarizing, and condensing.

\section{The implementation of the interpreter training course in IM to students who are not foreign language majors}

The three phases of IM: According to Chen (2010 a), to encourage diversity, each CAIT session should be divided into three phrases: warm-up, workout, and cooldown. In the warm-up phase, students are asked to talk in English about (but not limited to) what happened to them last weekend, or what they have read, to enhance their oral skills. The other students listen and take turns interpreting into another language. In the workout phase, students perform interpreter training tasks, with the assistance of CD ROMs and the computer, to enhance their interpretation skill. In the cool-down phase students, who have been designated to research on a specific topic on interpreter training, give PowerPoint presentations to enhance their interpretation knowledge and hone their public speaking skills.

Materials and equipments: Two types of materials are used in the classroom: (a) a textbook Putting Everyday English into Practice (Live ABCInteractive English Teaching Conglomerate, 2006),

that comes with CD ROMs and, (b) articles and related audios from the Special English section of Voice of America (http://www.voanews.com), chosen by each student for classroom interpretation practice. Students are encouraged to use VOA special English for practicing interpreter training tasks by themselves. The materials are chosen based on the assumption that they should cover a wide variety of topics and that they are supposed to be easy to understand and relevant to what the students are interested in learning. The content of the textbook is quite useful, including such topics as backpacking, ordering food in the restaurant, booking a room for a trip, changing money, 
etc. The instructor and students all have access to microphones, multimedia computers, and the Internet in the interpreter training laboratory.

A typical procedure of the workout phase in IM:

- Summarizing: The instructor plays the video and then asks students to summarize it in either English or Chinese.

- Paraphrasing: The instructor plays the video and then asks students to listen and then repeat in their own words what they have heard.

- Reading aloud: The instructor plays the CD ROM on the multimedia computer and turns on both the Chinese subtitles and the English subtitles for students, who are designated at random, to take turns reading the subtitles aloud. One student reads the English subtitles and then calls on, at random, the next student to read the Chinese subtitles. Attention is given to accuracy in pronunciation specifically in English in terms of voice, intonation, pitch, time, tune, emotion, and emphasis.

- Reading aloud and consecutive interpretation: The instructor turns on the English subtitles and turns off the Chinese subtitles. A student is called on, at random, to read the English subtitles aloud. This student does it and then calls the next student, at random, to interpret consecutively, without the support of the subtitles.

- Shadowing and simultaneous interpretation: The instructor plays the CD ROM and turns off both the Chinese and the English subtitles. A student is called on to shadow, and another student is called on to interpret simultaneously into Chinese. This can be done by students doing pair works in the classroom by whisper interpreting, or "chuchotage".

- $\quad$ Reading aloud in Chinese and consecutive interpreting into English: After the students have practiced interpreting a lesson in the CD ROM, the instructor plays the same lesson, turns off the English subtitles and audio, but turns on the Chinese subtitles. One student reads the Chinese subtitles aloud and then calls on the next student at random to interpret into English. They take turns doing so until the completion of the unit. This task may also be performed in the simultaneous mode.

Interpreting in the booth: Toward the end of the semester, students take turns interpreting in the booth of talks delivered by the other students, who take turns brain storming. Each student is required to interpret in the booth for ten minutes. Students, who are assigned to be speakers, are required to talk about what they have done over the weekend, about a controversial topic, or about an article they have read. Their speeches are usually predictable and not very difficult, so when interpreting such talks in the booth, the students concentrate on enhancing their SI skills.

Self-training: Because the students have different language backgrounds, language abilities, and motivations, self-training becomes the most important factor that can affect their learning. All the tasks practiced in the classroom can also be practiced during self-training or practicing with peers. Students also have the CD ROMs that come 


\section{Comparative Legilinguistics 4/2010}

with the textbooks. All the tasks may be practiced by using MP3 players or CD ROMs in personal computers or cell phones. It is up to the students to decide how much time they would like to spend on self-training.

Testing and evaluation: Each student's grade is assigned based on class attendance, classroom participation, a PowerPoint presentation, and interpreting for ten minutes at the end of the semester.

- Mid-term examination: In the mid-term examination, which is spread through out the semester, each student gives a 10-minute PowerPoint presentation per semester on a topic related to interpreter training, e.g. sight translation, consecutive interpretation, or simultaneous interpretation with the purpose of enhancing their interpretation knowledge and honing their public speaking skills because a good interpreter must also be a good public speaker.

- Final examination: In the final examination, the students are required to interpret for ten minutes in a mode of interpretation they have chosen. The students' grades are assigned based on the difficulty of the mode of interpreting they use, the difficulty of the materials they choose, and the language they choose to interpret into. They download audio or video materials from the Internet, such as VOA, and practice as many times as they need before interpreting in front of the class without referring to any texts. They get a higher grade if they perform long consecutive interpretation (that lasts for over one minute) with note-taking, medium grades if they perform SI, and lowest grades if they perform short CI. Students who interpret into English receive higher grades than those interpreting into Chinese. Several other factors may also affect their grades. They include: difficulty of the materials, interpretation quality, and consistency of the quality. The entire testing processes are video recorded for self critiques, peer reviews, and detailed grading.

\section{Results and discussion}

Students' reactions in the interpretation course in the IM approach have mostly been positive. I asked the students to provide feedback at the end of each class session and adjusted the teaching accordingly. The students' reactions to this course have been quite positive as shown below.

At the beginning, everything was difficult, but as the course continued, tasks became easier to handle: Most of the students commented that this course was quite challenging but full of fun. Some students posited that the textbook was too easy, but most of the other students said that it was ok. They all felt that at the beginning everything was very difficult, and they had to concentrate all the time, but as the course proceeded, the tasks became easier and easier to perform.

Many factors can affect learning: Students indicated that their learning was affected by the following factors, which were mainly related to the source language input: difficulty of learning materials, accents, speed of delivery, and required background knowledge. However, they indicated that the most difficult part was memory and consecutive note taking. They said that short consecutive interpreting was ok for them, but long consecutive interpreting was problematic because even with CI note taking, they did not have the ability to remember what the speaker had said. However, the most 
difficult tasks were summarizing and paraphrasing. More training is definitely needed for them to be able to interpret proficiently.

IM motivated students to interpret and arouse their interest in learning interpreting: At the end of the semester, I asked the students if they were asked by their future company to interpret at a workshop or conference, would they accept the job. They said that if they had been given plenty of time and related materials to prepare in advance, they would be able to know how to prepare and would be able to interpret well.

Assignments were reasonable: The students said that the assignments were acceptable but they unanimously agreed that they should not take more assignments or homework in this course because they had other assignments from other courses, especially their required courses, that they had to work on.

Students were motivated to perform the most challenging tasks during the final exam: Due to student empowerment, the students all interpreted for approximately 10 minutes during the final examination without referring to the text as required. Their interpretations were video recorded for detailed grading. Thirteen students performed short CI, obviously to play it safe. Three students did medium CI, and 2 students did SI. All the students interpreted from English into Chinese except one, who interpreted from Chinese into English. Two students used the cell phone to play the speech audio and interpreted consecutively. They said that that was how they practiced. It is quite an innovative way to practice interpreting. Would they take the course again if there is a chance? Most students agreed that this interpretation course was fun and interesting and that they would take it if it would be offered again under a different course number. For this reason, I offered "Introduction to Interpretation II" under a different course number the following semester. However, one student said that it was difficult for her to overcome the nervousness when she was called upon at random to interpret in the classroom. Finally they unanimously agreed that nobody had ever showed them that studying English could be so much fun.

The results of the existing study indicated that IM is a feasible alternative method for teaching English as a foreign language at an intermediate level to students who are not foreign language majors. The students prefer Basic Interpretation to other English courses because it was interesting and fun, it made them concentrated all the time, and the learning results were easily noticeable. From my observations, IM can enhance students' pronunciation, public speaking, reading comprehension, listening comprehension, interpretation, and communication skills in English. Based on my observations of the students taking the tests, those students who had learned in IM systematically and attended classes regularly outperformed those who had missed several classes. In other words, there was an obvious correlation between learning in the classroom and testing results at the end of the semester.

Diversity is the key to successful implementation of a course in IM. Diverse learning materials and training tasks should be used to arouse students' interest in learning. The training materials should cover diverse topics and should be easy and interesting enough for students to learn but not so difficult as to frustrate them. Earlier studies indicated (Chen, 2007, Chen, 2010) that CAIT training processes should be in the form of a sandwich that include warm-up, workout, and cool-down. Training tasks and 


\section{Comparative Legilinguistics 4/2010}

materials should be recycled to enable students to concentrate on the development of their pronunciation skills, public speaking skills, interpretation skills, and paralinguistic skills.

Students should be empowered to choose the most challenging tasks and materials they can handle in the test. The sky is the limit. It is surprising to see how students could interpret difficult materials consecutively or simultaneously at the end of the semester. This study is limited in that it used the qualitative research method and data were collected through classroom observations and students' written and oral output. Researchers are encouraged to use quantitative research methods in future studies.

\section{Conclusion}

The results of the existing study indicated that IM is an interesting alternative of interpreter training and foreign language teaching method to students who are not foreign language majors. This study is significant in that interpretation courses have been offered to undergraduate students who are not foreign languages majors throughout the world; in addition, computers are being used more and more often in interpreter training laboratories, but hardly any previous studies have investigated the implications of applying CAIT in teaching students who are not foreign language majors. It is hoped that this existing study may shed light on both interpreter training and foreign language teaching. This existing study has methodologically investigated the theoretical basis, training task structuring, training materials, testing and evaluation, and students' reactions. Other researchers are encouraged to use this unique interpreter training approach in their specific settings, foreign languages, and students to determine its effectiveness. In addition, EFL instructors are encouraged to use this innovative foreign language teaching method in their classes with students of different language levels or use it as an alternative foreign language teaching method.

\section{Bibliography}

Allan, George. 2003. A critique of using grounded theory as a research method. Electronic Journal of Business Research Methods 2(1): 1-10.

Chang, Chia-chien. 2006. The creation of an online learning community in interpreter training. Tai Wan Di Shi Yi Jie Guo Ji Kou Bi Yi Jiao Xue Yan Tao Hui Lun Wen Ji (The Proceedings of the $11^{\text {th }}$ International Translation and Interpretation Conference in Taiwan): 143-151.

Chen, Sheng-jie. 2007. Computer assisted interpreter training, a pilot study. Paper presented at NUCITTA Conference at the University of New Castle upon Tyne, 10 November 2007 in New Castle, United Kingdom.

Chen, Sheng-jie. 2010a. Computer assisted interpreter training: a case study. Studies in English Language and Literature 25: 17-41.

Chen, Sheng-Jie. 2010b. Applying the Blackboard Learning System to a mixed-language interpreter training course ---A Taiwan pilot study. Paper presented at the international conference, "Emerging Topics in Translation and Interpreting”,1618 June 2010, at the University of Trieste, Italy. 
Guo Li Tai Wan Shi Fan Da Xue Fan Yi Yan Jiu Suo, and Tai Wan Jing Ji Yan Jiu Yuan. 2004. Tai wan fan yi chan ye xian kuang diao cha yan jiu zong jie fen xi bao gao. Tai Bei: Tai Wan Xing Zheng Yuan Xin Wen Ju (Graduate Institute of Translation and Interpretation, National Taiwan Normal University, and Taiwan Institute of Economic Research. 2004. A final report on the current situations of the translation industry in Taiwan. Taipei: The Government Information Office of the Executive Yuan, Taiwan).

Herber, Harold L., and Joan Nelson Herber. 1993. Teaching in content areas with reading, writing, and reasoning. Needham Heights, M.A: Allyn \& Bacon.

Hogan, Kathleen, and Michael Pressley. 1997. Scaffolding student learning: Instructional approaches \& issues. Cambridge, M.A: Brookline Books, Inc.

Live ABCInteractive English Teaching Conglomerate.

2006. Lao wai jiao ni shuo ying yu shi zhan ying yong pian (Putting everyday English into practice). Tai Bei (Taipei): Xi Bo Lun Gong Si.

Miller, Neal. E., and John Dollard.1941. Social learning and imitation. New Haven: Yale University Press.

Sandrelli, Annalisa. 2001. Teaching liaison interpreting: Combining tradition and innovation. In Mason, Ian. Triadic Exchanges. En. Manchester: St Jerome Publishing: 173- 196.

Sandrelli, Annalisa. 2003. New technologies in interpreter training: CAIT. Textologie und translation. In Gerzymisch-Arbogast, Heidrun; Eva Hajicová; and Petr Sgall, Zuzana Jettmarová, Annely Rothkegel, Dorothee Rothfuß-Bastian. Tübingen: Gunter Narr Verlag (Jahrbuch Übersetzen und Dolmetschen 4/II). Eds.: 261-293.

Sandrelli, Annalisa, and Jesús de Manuel Jerez. 2007. The impact of information and communication technology on interpreter training. The Interpreter and Translator Trainer 1(2): 269-303.

Strauss, Anselm, and Juliet Corbin. 1990. Basics of qualitative research: Grounded theory procedures and techniques. Thousand Oaks, CA: Sage Publications.

Strauss, Anselm, and Juliet Corbin. 1998. Basics of qualitative research: Techniques and procedures for developing grounded theory, 2nd ed. Thousand Oaks, CA: Sage.

Tharp, Roland G., and Ronald Gallimore.1988. Rousing minds to life. New York: Cambridge University

Press.

Vygotsky, Lev Semyonovich.1978. Mind and society: The development of higher mentalprocesses.

Cambridge, MA: Harvard University Press.

\section{Internet Bibliography}

Dawrant, Andrew, and Jiang Hong. 2001. Conference interpreting in Mainland China. http://www.aiic.net/ViewPage.cfm?page id=365 (accessed November 20, 2007). 
Sandrelli, Annalisa, and Jim Hawkins. 2006. Computer assisted interpreter training (CAIT): What is the way forward?

http://www.upf.edu/bolonya/obolonya/titulac/upf/trad/docs/cait.pdf (accessed July 30, 2009).

Voice of America. (http://www.voanews.com (accessed July 30,2009).

Yang, Cheng-su .2002. Kou yi jiao xue de shu wei hua yu wang lu hua (Digitalizing and online interpreter training). http://www.itbi.edu.tw/ (accessed July 30, 2009).

Yang, Cheng-su. 2003a. Kou yi de wang lu jiao xue: shi ti ke tang yu xu ni ping tai de hu dong guan xi (Online interpreter training: The interactions between real classrooms and virtual classrooms). http://www.itbi.edu.tw/ (accessed July 30, 2009).

Yang, Cheng-su. 2003b. Tai Wan yin ying quan qiu hua qu xiang de kou yi ren cai pei xun fang an jie an bao gao shu (A project report on the training of interpreters for Taiwan to meet the needs of globalization). http://www.itbi.edu.tw/ (accessed July 30, 2009). 